\title{
Awareness Appraisal of Farmers about Abortion in Dairy Animals
}

\author{
Manoj Kumar Sharma* and Harish Kumar Verma
}

\author{
Department of Veterinary and Animal Husbandry Extension Education \\ Guru Angad Dev Veterinary and Animal Sciences University, Ludhiana, India \\ *Corresponding author
}

\begin{tabular}{|c|c|}
\hline & A $\mathbf{B} T R A C T$ \\
\hline & \multirow{6}{*}{$\begin{array}{l}\text { The awareness of the dairy farmers about causes and control measures of a disease helps in } \\
\text { avoiding the losses due to that disease. A study was undertaken to determine the awareness } \\
\text { status of dairy farmers about various causes and control and preventive measures of } \\
\text { abortion in dairy animals. Pre-structured and pre-tested interview schedule was presented } \\
\text { to one hundred and twenty respondents from Punjab, who had visited GADVASU, } \\
\text { Ludhiana. The questionnaire had fifty questions, each of one mark, twenty five related to } \\
\text { various causes of abortion and rests were related to control and preventive measures. The } \\
\text { score of the respondents about various causes of abortion varied from } 3 \text { to } 20 \text { with a mean } \\
\text { score of } 12.06 \pm 0.485 \text { (S.E.) out of } 25 \text {, while the score of the respondents about } \\
\text { management, control and preventive measures of abortion varied from } 4 \text { to } 20 \text { with a mean } \\
\text { score of } 13.54 \pm 0.451 \text { (S.E.). The total score of the respondents about all aspects of } \\
\text { abortion varied from } 10 \text { to } 38 \text { (Out of } 50 \text { ) with a mean score of } 25.61 \pm 0.857 \text { (S.E.). The } \\
\text { results revealed that farmers had low awareness about various aspects i.e. causes, } \\
\text { management, control and preventive measures of abortion in dairy animals. However, the } \\
\text { awareness level was significantly positively correlated with education level, herd size and } \\
\text { training of the farmers. So, there is need to create awareness amongst dairy farmers about } \\
\text { various causes, control and preventive measures through various awareness programmes to } \\
\text { prevent abortion in dairy animals. This will help them to modify their rearing practices } \\
\text { accordingly and avoid potential losses occurring due to it. }\end{array}$} \\
\hline Keywords & \\
\hline $\begin{array}{l}\text { Awareness } \\
\text { Appraisal of } \\
\text { farmers, } \\
\text { Abortion in dairy } \\
\text { animals }\end{array}$ & \\
\hline Article Info & \\
\hline $\begin{array}{l}\text { Accepted: } \\
\text { 19 April } 2017 \\
\text { Available Online: } \\
10 \text { May } 2017\end{array}$ & \\
\hline & \\
\hline
\end{tabular}

\section{Introduction}

The success of a dairy farm is dependent on the four pillars of breeding, feeding, heeding and weeding. All these have to be precisely adopted to have maximum benefit/profit. Fertility of the animals directly affects the reproduction and thus in turn production level of the dairy farm. The increase in production is directly related to good reproductive efficiency of the animals. Economic viability of a dairy venture depends upon reproductive efficiency of its herd. Successful reproductive efficiency comprises the ability to mate, capacity to conceive, nourish the embryo and deliver the viable offspring on completion of the gestation period without any complication (Chand, 2011). Abortion in pregnant animal leads to multiple losses to the livestock owners in the form of loss of future progeny, reduced milk production, increased number of days open leading to enhanced intercalving period, treatment cost and infection carrier and threat to other healthy animals. Each abortion is estimated to cost to the dairy farmers Rs. 30,000-50,000 depending on milk 
and feed prices, replacement stock and the stage of gestation when the abortion occurs (Verma et al., 2015).

The awareness among the livestock farmers about various causes and control and prevention measures against abortion can play a significant role in avoiding the losses. Awareness of the farmers will protect their animal wealth and will reduce the avoidable losses. This basic study was aimed at assessing the awareness level of the farmers about various aspects of abortion in dairy animals and listing the knowledge gaps which can help in formulating suitable awareness programmes for the livestock farmers.

\section{Materials and Methods}

The study was conducted at campus of Guru Angad Dev Veterinary and Animal Sciences University, Ludhiana, Punjab. The sample size consisted of randomly selected one hundred and twenty farmers belonging to different areas of the state. Data were collected through a pre-structured and pretested interview schedule questionnaire. Questionnaire was divided into two parts. First part had 25 questions related to general terminology and etiologies while second part included 25 questions dealing with management, control and preventive measures of abortion. One mark was assigned for each correct answer. Selected socio-personal characteristics of the respondents were also recorded. The data was tabulated and analyzed statistically to draw inferences.

\section{Results and Discussion}

The majority of the respondents fell into young age groups i.e. $84.16 \%$ of the respondents were less than 40 years of the age. This indicates the increased adoption of dairy farming as a profession by the youth of the state. The majority of the respondents
$(67.5 \%)$ were having education up to higher secondary school level. $30 \%$ of respondents had studied up to graduation level while $2.5 \%$ were having post graduate qualifications. Majority of respondents $(55.5 \%)$ were members of the joint families while rest of the $45.5 \%$ were having nuclear families. Mixed faming comprising of agriculture with dairy farming, was being practiced by majority 92 (76.7\%) of respondents followed by $23.3 \%$ practicing only dairy farming, indicating the trend of venturing into dairy farming sector. A very high majority of respondents 102 $(85 \%)$ did not have any formal training on dairy farming while rest of the 18 (15\%) were rearing animals without any training. Eighty eight $(73.3 \%)$ respondents were having herd size less than 10 while remaining $32(26.7 \%)$ farmers were having herd size more than 10 . Television was found out to be the mass media source followed by highest majority $117(97.5 \%)$ of the study group followed by newspaper $93(77.5 \%)$, Internet 82 (68.3\%), radio $44(36.7 \%)$ and farm magazines 28 $(23.3 \%)$.

After testing, the score of the respondents about various causes of abortion varied from 3 to 20 with a mean score of $12.06 \pm 0.485$ (S.E.) out of 25, while the score of the respondents about management, control and preventive measures of abortion varied from 4 to 20 with a mean score of $13.54 \pm 0.451$ (S.E.) out of 25. The total score of the respondents about all aspects of abortion varied from 10 to 38 (Out of 50) with a mean score of $25.61 \pm 0.857$ (S.E.). Overall, 64 $(53.3 \%)$ respondents fared poorly scoring less than 25 marks out of 50. Thirty seven $(30.83 \%)$ respondents scored in the range of 25 to 35 marks. Only 13 (10.83\%) respondents fell into very good score category, scoring 35 to 45 marks. Very few 6 $(5.0 \%)$ respondents were able to score 45 or more marks. This clearly showed that the knowledge of the farmers about various 
abortifacients and their control and prevention was low.

Similar results were reported in studies conducted by Singh et al., (2012) and Singh et al., (2014), who reported lower levels of awareness among dairy farmers of Punjab about common toxicities and safe animal handling practices respectively. They also stressed on the need for organisation of specific seminars and practical training of the farmers regarding safe animal practices. In another study, Sharma et al., (2015) found that the awareness level of the dairy farmers about risks and various preventive measures against Brucellosis was quite low.

Table.1 Socio-Personal characteristics of the respondents and their correlation with obtained score

\begin{tabular}{|c|c|c|c|}
\hline Factor & Variable & Respondents & $\begin{array}{c}\text { Correlation } \\
\text { coefficient (' } r \text { ') \& } \\
\text { Significance }\end{array}$ \\
\hline \multirow{4}{*}{$\begin{array}{c}\text { Age } \\
\text { (Years) }\end{array}$} & Up to 25 & 38 & \multirow[t]{2}{*}{-0.0498} \\
\hline & $25-40$ & 63 & \\
\hline & $41-60$ & 16 & \multirow[t]{2}{*}{ 'NS' } \\
\hline & Above 60 & 3 & \\
\hline \multirow[t]{5}{*}{ Education } & Illiterate & 0 & \multirow[t]{2}{*}{0.4768} \\
\hline & Below Metric & 14 & \\
\hline & Higher Secondary & 67 & \multirow{3}{*}{ ' $\mathrm{S}$ ' } \\
\hline & Graduate & 36 & \\
\hline & Post Graduate & 3 & \\
\hline \multirow{2}{*}{ Training } & Obtained & 18 & \multirow{2}{*}{$\begin{array}{c}0.5842 \\
\text { 'S' }\end{array}$} \\
\hline & not obtained & 102 & \\
\hline \multirow[t]{2}{*}{ Herd size } & $<10$ & 88 & \multirow{2}{*}{$\begin{array}{c}0.4631 \\
\text { ' } \mathrm{S} \text { ' }\end{array}$} \\
\hline & $>10$ & 32 & \\
\hline \multirow[t]{2}{*}{ Occupation } & Dairy Farming only & 28 & \multirow{2}{*}{$\begin{array}{c}0.0811 \\
\text { 'NS' }\end{array}$} \\
\hline & Mixed Farming & 92 & \\
\hline \multirow{2}{*}{ Family type } & Nuclear & 56 & \multirow{2}{*}{$\begin{array}{c}0.0164 \\
\text { 'NS' }\end{array}$} \\
\hline & Joint & 64 & \\
\hline \multirow{5}{*}{$\begin{array}{l}\text { Mass Media } \\
\text { Exposure }\end{array}$} & Radio & 44 & \multirow{5}{*}{$\begin{array}{c}0.0948 \\
\text { 'NS' }\end{array}$} \\
\hline & Television & 117 & \\
\hline & Internet & 82 & \\
\hline & Newspaper & 93 & \\
\hline & Farm Magazines & 28 & \\
\hline
\end{tabular}

'NS'- Non Significant; 'S' - Significant 
Table.2 Score obtained by the respondents

\begin{tabular}{|l|l|l|l|}
\hline $\begin{array}{l}\text { Knowledge } \\
\text { Criterion }\end{array}$ & $\begin{array}{l}\text { General terminology } \\
\text { and causes of abortion } \\
\text { (Mean } \pm \text { S.E.) }\end{array}$ & $\begin{array}{l}\text { Management, control } \\
\text { and prevention of } \\
\text { Abortion } \\
\text { (Mean } \pm \text { S.E.) }\end{array}$ & $\begin{array}{l}\text { Overall knowledge } \\
\text { about abortion in } \\
\text { dairy animals } \\
\text { (Mean } \pm \text { S.E.) }\end{array}$ \\
\hline $\begin{array}{l}\text { Score of the } \\
\text { respondents }\end{array}$ & $12.06 \pm 0.485$ & $13.54 \pm 0.451$ & $25.61 \pm 0.857$ \\
\hline
\end{tabular}

Table.3 Categorisation of the respondents based on the total score

\begin{tabular}{|c|c|}
\hline Total Score (out of 50) & Number of Respondents \\
\hline $45-50($ More than $90 \%)$ & 6 \\
\hline $35-45(70-90 \%))$ & 13 \\
\hline $25-35(50-70 \%)$ & 37 \\
\hline $0-25($ Less than 50\%) & 64 \\
\hline
\end{tabular}

The dairy animals and farmers of Punjab were at greater risk for Brucellosis, owing to its higher incidence in the state. In our study also, the farmers had low awareness about various aspects i.e. causes, management, control and preventive measures of abortion in dairy animals.

The correlation analysis of various socio personal characteristics with the obtained scores revealed that education level, herd size and training of the respondents had a significant positive correlation among them and other factors did not yield any significant correlation with the obtained score. Similar positive correlation between knowledge level and education level, herd size and training status of the respondents was also reported in the different studies conducted by Patil et al., (2009), Singh et al., (2012) and Singh et al., (2014). This indicates towards the requirement of extension programmes to make farmers aware about various aspects (causes, management and control \& prevention) of abortion in dairy animals so that farmers can adopt recommended scientific practices and avoid losses due to abortion.
In conclusion, from the above results, it can be concluded that the awareness level of the farmers about causes and various preventive measures against abortion in dairy animals was low. This point towards the risk proneness of dairy animals towards abortion, owing to lower knowledge level of the farmers, so, there is an immediate need to make the farmers aware about various causes and various preventive measures against abortion in dairy animals through literature, awareness campaigns cum training programmes and mass media methods.

\section{References}

Chand, S. 2011. Analysis of reproductive disorders in dairy animals in Alwar district of Rajasthan. M.Sc.Thesis, NDRI (Deemed University), Karnal.

Patil, A. P., Gawande, S. H., Nande, M. P. and Gobade, M. R. 2009. Assessment of knowledge level of dairy farmers in Nagpur district and the co-relation between socio-economic variables with their training needs. Veterinary World 2(5): 199-201.

Sharma, M. K., Verma, H. K. and Kasrija, R. 2015. Awareness of Dairy Farmers 
about Brucellosis Disease. Journal of Animal Research 5(3): 645-648.

Singh, B., Singh, J. and Sharma, V. L. 2012. Assessment of farmers' knowledge about safe handling Practices of dairy animals. Indian Res.J.Ext.Edu.12 (2): $130-134$.

Singh, J., Hundal, J. S., Verma, H. K. and Kansal, S. K. 2014. Awareness among dairy farmers of Punjab about common toxicities in ruminants. Haryana Vet.
(Dec., 2014) 53 (2): 130-132.

Verma, H. K., Sharma, M. K. and Kasrija, R. 2015. Infectious abortions in dairy animals. Compendium of lectures of training programme on control of infectious animal diseases held at Department of Veterinary Medicine, College of Veterinary Science, Guru Angad Dev Veterinary and Animal Sciences University Ludhiana from 27th to 31st January, 2015: 60-67.

\section{How to cite this article:}

Manoj Kumar Sharma and Harish Kumar Verma. 2017. Awareness Appraisal of Farmers about Abortion in Dairy Animals. Int.J.Curr.Microbiol.App.Sci. 6(5): 1850-1854. doi: https://doi.org/10.20546/ijcmas.2017.605.202 